\title{
Climate Justice: A New Social Movement for Atmospheric Rights
}

\section{Jethro Pettit*}

Many of those in the front lines of climate change negotiations are frustrated. The global policy process is moving too slowly in relation to the scale of the problem. Political will is lacking, not only in the North and particularly in the USA, as is well known, but now increasingly in the South as well, in response to the North's foot-dragging, to Organisation of Petroleum Exporting Countries (OPEC) pressure, as to perceptions that economic growth will suffer. Civil society coalitions, in the North and the South, are as yet too weak to bring sufficient pressure. 'The chances of our getting anywhere near where we need to be with international diplomacy are grim,' one policy advocate said. 'We need other forces. What might these be and what are the chances of mobilising them?' This article asks what social movements are emerging as a force for action on climate change, to reinforce the efforts of sympathetic non-governmental organisations (NGOs) and diplomats. Specifically, it asks how such social movements might urge international development actors to move more squarely into the arena from their stance on the sidelines and to recognise climate change as one of the greatest risks to poor peoplea force capable of literally "undoing" decades of development. There is also a need to reconcile the sometimes conflicting messages and objectives of civil society coalitions working on the issue in the North and South and to move from protest and criticism to concrete proposals.

In the North, civil society has concentrated on climate change more exclusively as an environmental issue, by environmental NGOs and researchers and has focused on scientific and technical solutions such as emissions controls and carbon credits. In the South, however, climate change has emerged primarily as a sustainable development issue, whose solutions are seen as inseparable from larger issues of poverty, trade and globalisation. These messages have yet to appear in Northern development discourses and in the policies of international NGOs, though these have begun to address issues of poverty impacts and adaptability (Newell 2000). Climate change is already on the agenda for many marginalised people concerned with protecting their social and economic rights, North and South. From a rapid review of the landscape, they are making links between poverty and climate change in ways that differ from the mainstream international development community. Some social movements are articulating their messages within the theme of antiglobalisation, connecting climate change with unjust North/South economic relations. Others build on long-standing traditions of "environmental justice" campaigns, which have been concerned with the hugely disproportionate impact of pollution and ecological degradation on poor communities. Together, these diverse social forces have adopted "climate justice" as a rallying cry.

The climate justice message is that poor people have not been "waiting for the science" on global warming. They have been living with it - and with many other forms of pollution and degradation for many years, as "social sinks" for the externalisation of environmental costs. Articulated in the language of rights, their foremost concern about climate change is with who is responsible for this enormous new threat to their survival. Rather than asking how we can mobilise them on climate issues, a more important question may be how they can further mobilise and align themselves as a global political force with influence at multiple levels - and perhaps in doing so compel those of us in the poverty industry to take a much stronger stand both on the life-threatening poverty effects of climate change 
and more importantly, on addressing its primary causes within our own societies and economies.

It is worth listening to these voices and to their differing articulations of climate-poverty links and causes. By and large, the framing of "climate justice" reflects the same social and economic rights perspectives voiced by global movements on debt, trade and globalisation. But it is not yet clear that they have been able to mobilise themselves as boldly, or to develop as effective strategies for influencing opinion, or to find sufficient common ground with climate change activists from mainstream environmental organisations. Nonetheless, there are signs of a genuine movement, albeit one with more to offer in the form of protest than constructive alternatives and broader alliances at this stage. Parallel to UN climate negotiation sessions, there have been alternative summits of environmentalists, including climate justice advocates and representing a range of views on the merits of the official proceedings. In India, the 8th Conference of the Parties (COP 8) held in 2002 under the UN Framework Convention on Climate Change (UNFCCC) was accompanied by a Climate Justice Summit attended by hundreds of activists from throughout the country, including farmers, fisherfolk, indigenous people, women, youth and the urban poor (Khastagir 2002). Delhi's rickshaw drivers, banned from the "cars only" city centre came out in force and in defiance of police barricades. ${ }^{1}$ The resulting Delhi Climate Justice Declaration cited the unequal impact of climate change on poor people and the exclusion of the poor who are most affected from global processes to address the issue:

We affirm that climate change is a rights issue it affects our livelihoods, our health, our children and our natural resources. We will build alliances across states and borders to oppose climate change inducing patterns and advocate for and practice sustainable development. We reject the market based principles that guide the current negotiations to solve the climate crisis: Our World is Not for Sale! (India Climate Justice Forum 2002)

Until the final sentence, this statement is consistent with mainstream development messages on poverty and climate change. Where it diverges is in its reservations about relying upon market solutions, which are seen as having caused the problem in the first place. Elsewhere in the declaration, climate change is recognised (as science and economics also confirm) as originating largely from the activities of industrialised nations and from 'unsustainable production and consumption practices ... primarily in the North but also in the South' (India Climate Justice Forum 2002). The North/South dimension of cause and effect has not been lost on the UN Climate Change Convention itself, which asks the largest per capita emitters of greenhouse gasses (GHG) to take the greatest share of responsibility. The developing countries have largely signed up to Kyoto. But for some climate justice advocates, the protocol falls down by absolving the North of its moral and historical responsibilities (the latter, when calculated, shift the emissions burden even further north). ${ }^{2}$ An exception is the Brazilian proposal, which seeks to link future commitments to historical responsibilities for temperature rises. But Kyoto is still largely perceived by the climate justice movement as a way for the North to buy its way out of altering its unsustainable consumption patterns by trading carbon credits with the South. Some in Delhi "proclaimed that multinational corporations and industrialised nations had hijacked the Kyoto negotiations' (Khastagir 2002: 4).

In the North, where environmental justice has deep roots, social movements have also taken up climate change as a rights issue - but are more supportive of Kyoto, whose neo-conservative opponents are also long-term adversaries of the civil rights and anti-poverty movements. Their messages emerge from long-standing struggles over the adverse and disproportionate impact of toxic waste and pollution on poor and minority communities (cf. Bullard 1996). Climate change has been adopted as a central plank of this movement, reflected for example in the Environmental Justice and Climate Change Initiative (2002), a coalition of dozens of religious and civil rights organisations advocating 'the fair treatment of people of all races, tribes and economic groups in the implementation and enforcement of environmental protection laws' (Environmental Justice and Climate Change Initiative 2002). They call attention to a litany of scientific studies linking pollution, health, poverty and race in the USA, ${ }^{3}$ and see more disaster on its way with climate change because 80 per cent of people of colour and 
indigenous people live in coastal regions (US Census Bureau 1999, cited in EJCCI 2002).

The Climate Justice Summit held in The Hague in 2000, which paralleled COP 6, was attended by a strong delegation of black, Hispanic and indigenous leaders from the environmental justice movement in North America, who also held their own Forum (Bullard 2000). While there was some scepticism about the official UN proceedings, seen by some as "mired in "smoke and mirror" technical discussions and sessions dominated by "emissions brokers" and corporate lobbyists' (Bullard 2000: 2), these groups largely support the Protocol and advocate that it should be signed by the USA. Kyoto had recently become a political football, in which the energy lobby was playing the race card and abusing the language of environmental justice:

A coal lobby group, Center for Energy and Economic Development (CEED), funded a $\$ 40,000$ study blasting the Kyoto Protocol ... The report entitled 'Refusing to Repeat Past Mistakes: How the Kyoto Climate Change Protocol Would Disproportionately Threaten the Economic Well-Being of Blacks and Hispanics in the United States' was trotted out by several minority business and labor organisations ... none of which have an environmental or environmental justice track record. (Bullard 2000: 3)

The emergence of such industry-sponsored "citizen groups" in opposition to Kyoto, sometimes known as "AstroTurf" organisations, demonstrates how seriously the fossil fuel lobby takes the challenge of winning public opinion and legitimising its views through the media and contesting the terrain of civil society (Peter Newell, pers. comm. 2004). One strategy being used to counter this has been to create alliances with other sectors of industry that stand to suffer from climate change, such as insurance, tourism and agriculture, in order to challenge the notion that the fossil fuel lobby speaks for all industry (Peter Newell, pers. comm. 2004) Under the Bush administration, the political, social and racial lines around Kyoto have grown sharper within the USA and the climate justice cause has forged new alliances on both the "climate" and "justice" sides of its agenda. Their challenge under Bush, as for the worldwide movement, is to grow sharper teeth that can either break the political impasse or redefine the surrounding terrain. Climate justice needs to evolve from a parallel noise maker into a genuine pincer that cannot be ignored and into a strategic force that can have more direct impact.

Another strategy being attempted is litigation. The Inuit people of Canada and Alaska recently filed a lawsuit against the Bush Administration for posing a climate-related threat to their survival: 'By repudiating the Kyoto protocol and refusing to cut US carbon dioxide emissions, which make up 25\% of the world's total, Washington is violating their human rights' ${ }^{2}$ (Power 2003). State governments in the USA are taking similar action against the federal government (ICTA 2003). Litigation in the USA, even where it fails, has a history of being used to the strategic advantage of rights causes over time. According to the International Center for Technology Assessment, 'if it takes lawsuit after lawsuit to force the Bush administration to accept its responsibilities and pursue good public policy on this issue, then that's what it will face' (ICTA 2003). In legal terms, it is not just actions, but the failure to act that can be prosecuted as a violation of rights. However, even with this highly symbolic contribution, litigation can be very costly and difficult to access for poorer communities, so there are limits to what can be achieved (Peter Newell, pers. comm. 2004).

While the climate justice movement as a whole is divided in its hopes for Kyoto - at best impatiently supportive and at worst sceptically dismissive - its members resonate clearly on the "justice" side of their message. All of them emphasise the hugely disproportionate effects of climate change on their poverty and marginalisation, which they remind us is not a new issue and which they frame in the language of rights. All sound a note of political frustration and even alienation with regard to UNFCCC negotiations, whatever their view of its potential merits. All point to the need to address the underlying causes of climate change, which are seen as rooted in unjust economic relations at all levels and in unsustainable patterns of consumption by the North and by Southern elites. Much of the scepticism with Kyoto comes from a sense that these issues are not on the table, obfuscated by marketled emissions brokering. These are also sticking points for mainstream development actors, who would prefer to talk about poverty impacts and carbon-sinking strategies than social and economic 
structures. These issues take us away from the "low hanging fruit" of balancing carbon credits and into the much bigger, more awkward challenges of reengineering the way we live and consume in the North. While more vocal NGOs are taking up these issues in alliance with social movements, the development community as a whole is not engaged in the climate justice agenda, despite its rightsbased rhetoric.

On the positive side, it is clear that we have seen only the beginning of the climate justice movement and experience shows that global civil society initiatives can 'play an important role in configuring new patterns of global politics', shaping the scope and boundaries of policy debates even where their direct influence may be limited (Newell 2001: 191). Major challenges, nonetheless, lie ahead for this movement. One will be to strengthen its capacities to engage more effectively in policy and negotiation processes - building skills in direct political participation (Gaventa 2001: 286). These and other "lessons for good practice" from diverse experiences of global citizen action (Gaventa 2001: 279-84) suggest that climate justice is only beginning to find a voice that is likely to gain in strength, alliance and sophistication over time. Some would argue that the movement is playing an important "outsider" role in raising the issues and the stakes, so that "insiders" can make headway in policy and negotiations. But there is also doubt as to whether this "outsider-insider" strategy can work at a time when the process itself appears to be unravelling. The climate justice movement may therefore need to shift from protest to proposing alternatives and to reconciling differences with other sectors of climate change activism, as well as finding ways to build common ground with the international development community. Finding a common position on Kyoto would be a positive step. But

\section{Notes}

* I would like to thank Mark Kenber and Peter Newell for comments on an earlier draft of this article.

1. 'Said one rickshaw wallah: "the rich people drive around this district of Delhi one person to a car - they are contributing to the pollution. We do not make any pollution yet we are banned from being allowed to work in this district"' (Khastagir 2002: 4). even then, decisions will need to be made about whether to continue lobbying states to ratify Kyoto, or to tackle the biggest polluters and foot-draggers directly, such as the USA; clearly both are necessary, but which strategy makes strategic sense in the short term? (Peter Newell, pers. comm. 2004)

What can be learnt from other global justice campaigns, such as the Jubilee 2000 campaign on debt relief, for example? One lesson is that the campaign had clear proposals and demands, in addition to raising awareness and visible protest. Another is the value of building bridges and strategic alliances, even where there may not be total agreement. At a time when the climate change negotiations are at risk of unravelling altogether, there is a need perhaps for greater unity of purpose and more common proposals. This is difficult at present, given the divide between those in favour of market-based and voluntary programmes and those seeking more binding agreements and fundamental changes. The "insider-outsider" approach can only work if there are elements of a common vision and objective, but not if the campaigns are working at cross-purposes or worse, attacking each other. Points of unity and coordinated action are very much needed. Whatever form the agenda takes, the "climate justice" message is likely to gain in strength and credibility over time and will need to be reflected: that climate change must be tackled in an integral way with the problems of poverty and exclusion in the South and overconsumption and fuel dependence in the North. In this sense the development community, too, has a responsibility to find its common ground with the climate justice movement, to seek better understanding of the synergies and implications and to build mutual strategies for action on climate, poverty and social change in the North and South.

2. The World Resources Institute calculates that 60 per cent of annual carbon dioxide emissions originate in industrialised countries, where only 20 per cent of the world's population lives; historically the emissions ratio for industrialised countries shifts to 80 per cent (cited in Shah 2003: 2).

3. In the USA, large numbers of people of colour live in areas of sub-standard air quality. They are twice as likely to die in heat-related deaths (Centers for Disease Control 
and Prevention 1996) and three times as likely to be hospitalised or die from asthma and respiratory illnesses linked to air pollution (NEA Health Information Network, n.d.), both cited in EJCCI (2002).

4. As the Arctic region warms up and ice and snow diminish, 155,000 Inuit people are facing disaster, as their hunting

\section{References}

Bullard, R.D., 2000, Climate Justice and People of Color, Environmental Justice Resource Centre, Clark Atlanta University, USA, www.ejrc.cau.edu (accessed March 2004)

Bullard, R.D., 1996, Unequal Protection: Environmental Justice and Communities of Color, San Francisco: Sierra Club Books

Centers for Disease Control and Prevention, 1996, 'Asthma mortality and hospitalization among children and young adults - United States, 1980-93', Morbidity and Mortality Weekly Report 45: 350-3

Environmental Justice and Climate Change Initiative (EJCCI), 2002, About Us and Climate Change and Environmental Justice Fact Sheet, www.ejcc.org (accessed March 2004)

Gaventa, J., 2001, 'Global Citizen Action: Lessons and Challenges', in M. Edwards and J. Gaventa (eds), Global Citizen Action, Boulder, Colorado: Lynne Rienner

India Climate Justice Forum, 2002, Delhi Climate Justice Declaration, India Resource Centre, www.indiaresource.org (accessed March 2004) habitats vanish and the melting of permafrost causes their settlements to collapse. Sheila Watt-Cloutier, chairwoman of the Inuit Circumpolar Conference, says that her people 'are already bearing the brunt of climate change - without our snow and ice our way of life goes' (Power 2003).

International Center for Technology Assessment (ICTA), 2003, States Environmental Groups Challenge Bush on Global Warming, www.climatelaw.org/media/states.challenge.bush (accessed March 2004)

Khastagir, N., 2002, 'The human face of climate change', Global Policy Forum, www.globalpolicy.org (accessed March 2004)

NEA Health Information Network, n.d., Asthma, www.neahin.org/4c.html

Newell, P., 2001, 'Campaigning for Corporate Change: Global Citizen Action on the Environment', in M. Edwards and J. Gaventa (eds), Global Citizen Action, Boulder: Lynne Rienner; London: Earthscan

Newell, P., 2000, Climate for Change: Non-State Actors and the Global Politics of the Greenhouse, Cambridge: Cambridge University Press

Power, A., 2003, 'Inuit to launch human rights case against the Bush Administration', The Guardian, UK, 11 December

Shah, A., 2003, 'Climate justice and equity', Global Issues, www.globalissues.org (accessed March 2004)

US Census Bureau, 1999, American Housing Survey, Washington, D.C.: US Government 